\title{
137. Deciduomal Response to Uterine Traumatization in Immature Rats Given Progesterone-Estradiol Injections Following Priming with PMS.HCG ${ }^{1)}$
}

\author{
By Kiyoshi TAKEWAKI \\ Biological Laboratory, Muré School, Tokyo Woman's Christian College \\ and Zoological Institute, Faculty of Science, University of Tokyo \\ (Comm. by Yô K. OKadA, M. J. A., Sept. 12, 1969)
}

It is well established that uterine traumatization fails to elicit formation of deciduomata in immature rats with ovaries heavily luteinized by the PMS-HCG priming procedures of Parlow, although the ovaries are capable of secreting progestins in amounts sufficient to cause vaginal mucification in the animals in the presence of exogenous estrogen (Guillet and Rennels, 1964; Armstrong and Greep, 1965; Takewaki, 1969). The inability to form deciduomata in so treated rats has been discussed in relation to predominance in activity of $20 \alpha$-hydroxypregn-4-en-3-one over progesterone in the blood (see Takewaki, 1969).

The present experiments demonstrate that the uteri of immature rats primed by the Parlow's method, ovariectomized and subjected to daily injections of optimal progesterone-estradiol combinations supportive of deciduomal growth fail to react to trauma by formation of deciduomata.

Materials and methods Female rats of the $T$ strain used in these studies were bred and raised in the colony maintained in the Endocrinology Division, Zoological Institute, Faculty of Science, University of Tokyo.

Group 1. Fifteen rats receiving 40 I.U. PMS at 21 days of age and 20 I.U. HCG at 23 days, about 50 hours after PMS injection, each by a single subcutaneous injection, were ovariectomized 2 days after HCG administration.

Group 2. Nine rats were ovariectomized at 21 days of age and injected with 40 I.U. PMS soon after operation. An injection of 20 I.U. HCG was given about 50 hours later.

Group 3. Eight rats received 5 I.U. PMS at 21 days of age and 2 I.U. HCG at 23 days, about 50 hours after PMS. The animals were ovariectomized 2 days after the second injection.

1) Supported by a Grant-in-Aid for Fundamental Scientific Research from the Ministry of Education. 
The doses of PMS (Primantron, Schering A.G., Berlin) and HCG (Primogonyl, Schering A.G., Berlin) were dissolved in $0.1 \mathrm{ml}$ of $0.9 \% \mathrm{NaCl}$ solution. The ovaries removed were freed from extraneous tissues, weighed and fixed in Bouin's solution.

All rats of the 3 groups were given daily subcutaneous injections of $2 \mathrm{mg}$ progesterone and $0.2 \mu \mathrm{g}$ estradiol-17 $\beta$, dissolved together in $0.05 \mathrm{ml}$ sesame oil, for 7 consecutive days, the first injection being given at 25 days of age, immediately after operation in those ovariectomized on that day. On the 4th day of injection, the rats were anesthetized with ether and the right uterine horn was traumatized by making a longitudinal scratch on the antimesometrial surface of the endometrium along the entire length of the horn. For details of the technique, see Takewaki (1969). The animals received the progesterone-estradiol injections for 3 days longer, sacrifices being performed on the day following the last injection. This dose combination was used, because Yochim and De Feo (1962) reported that its daily injections yielded maximum deciduomal growth in response to traumatization in the uteri of ovariectomized adult rats.

At sacrifice, rats were weighed. Uteri were examined for gross evidence for deciduomata; traumatized and nontraumatized horns were weighed separately in a majority of animals and fixed in Bouin's solution. Sections cut in paraffin were stained with Delafield's hematoxylin and eosin.

Results and discussion.

1. Failure of uterine traumatization to elicit deciduoma formation in immature rats ovariectomized after having been primed with 40 I.U. PMS-20 I.U. HCG (Group 1).

Ovaries removed after priming were greatly enlarged with numerous corpora lutea, wieghing $126.8 \pm 7.4 \mathrm{mg}$ on the average. In all animals, some of the corpora lutea still retained an antrum.

Fifteen rats of this group invariably failed to develop deciduomata in response to uterine traumatization. Even microscopical nodules of deciduomal tissue were not encountered in their uteri, although traumatized horns were uniformly heavier than nontraumatized ones in 10 of the 15 rats in which the two horns were weighed separately (Table I, $95.3 \pm 3.2 \mathrm{mg}$ as against $72.9 \pm 4.8 \mathrm{mg}$ ). 2. Formation of deciduomata in response to uterine traumatization in immature rats ovariectomized prior to treatment with 40 I.U. PMS-20 I.U. HCG (Group 2).

Small immature ovaries of these rats $(13.1 \pm 1.3 \mathrm{mg})$ contained small solid and antral follicles but no corpora lutea.

At autopsy, 7 of 9 rats exhibited well developed deciduomata in traumatized uterine horns weighing $279.6 \pm 47.3 \mathrm{mg}$ (118-463 mg) 
Table I. Weights of traumatized and nontraumatized uterine horns in different groups of immature rats $(\mathrm{M} \pm \mathrm{SE} \mathrm{mg})$ given injections of $2 \mathrm{mg}$ progesterone and $0.2 \mu \mathrm{g}$ estradiol

\begin{tabular}{|c|c|}
\hline Traumatized horn & Nontraumatized horn \\
\hline \multicolumn{2}{|c|}{ Group 1 Ovariectomized after 40 I. U. PMS-20 I. U. HCG $(10)^{1)}$} \\
\hline $95.3 \pm 3.2$ & $72.9 \pm 4.8$ \\
\hline \multicolumn{2}{|c|}{ Group 2 Ovariectomized prior to 40 I. U. PMS-20 I. U. HCG (7) } \\
\hline $279.6 \pm 47.3$ & $84.7 \pm 2.6$ \\
\hline \multicolumn{2}{|c|}{ Group 3 Ovariectomized after 5 I. U. PMS-2 I. U. HCG (8) } \\
\hline $356.1 \pm 56.4$ & $110.9 \pm 4.9^{2)}$ \\
\hline
\end{tabular}

1) Number of rats.

2) The mean of values from 7 rats is given, since deciduomata were developed in both horns in 1 animal.

on the average (Table I). Nontraumatized horns were much smaller, averaging $84.7 \pm 2.6 \mathrm{mg}$ in weight.

It is apparent from the foregoing results that treatment with 40 I.U. PMS and 20 I.U. HCG rendered the uteri of immature rats unresponsive to trauma through the ovaries. The rats were totally nonreactive to uterine trauma even if they were placed on a daily injection regimen of $2 \mathrm{mg}$ progesterone plus $0.2 \mu \mathrm{g}$ estradiol. In the absence of the ovaries, the PMS-HCG treatment was without effect in this respect. Ovarian factor (or factors) involved in this event might be estrogen, although determination of its nature requires further study.

The nontraumatized horns of this group of rats were significantly heavier than those of Group 1 rats which received similar injections of progesterone plus estradiol but failed to form deciduomata $(\mathrm{P}<$ 0.001). This also shows difference in reaction of the uteri to the administered progesterone-estradiol combination between the two groups of rats.

3. Formation of deciduomata in response to uterine traumatization in immature rats ovariectomized after having been treated with 5 I.U. PMS-2 I.U. HCG (Group 3).

In the previous paper, the writer (1969) reported that, although continued injections of prolactin were incapable of evoking deciduomal response to uterine trauma in immature rats with ovaries heavily luteinized by injections of 40 I.U. PMS and 20 I.U. HCG, positive deciduomal reaction was obtained following similar injections of prolactin in a majority of immature rats which had been pretreated with 5 I.U. PMS and 2 I.U. HCG. Accordingly, it was thought interesting to study whether the uterus is capable of forming de- 
ciduomata in response to traumatization, if rats treated with 5 I.U. PMS-2 I.U. HCG are ovariectomized and given daily injections of $2 \mathrm{mg}$ progesterone plus $0.2 \mu \mathrm{g}$ estradiol.

Ovaries of this group of rats averaged $28.8 \pm 1.1 \mathrm{mg}$ in weight, containing 4-8 solid and antrum-bearing corpora lutea. At autopsy, deciduomata were found in all animals, traumatized horns of 8 rats averaging $356.1 \pm 56.4 \mathrm{mg}(148-582 \mathrm{mg})$ in weight. In one of the 8 rats, nontraumatized horn also bore deciduomata $(234 \mathrm{mg})$. Nontraumatized horns without deciduomata of the remaining 7 rats averaged $110.9 \pm 4.9 \mathrm{mg}$ in weight.

In this group of rats, deciduomal response was greater than in Group 2 animals, difference in mean weight of uterine horns bearing deciduomata between the two groups being statistically significant $(\mathrm{P}<0.01)$. The greater response in Group 3 than in Group 2 might be ascribable to exposure of the uteri to endogenous estrogen prior to injections of progesterone plus estradiol in the former. Significant difference in weight of nontraumatized uterine horns between Groups 2 and $3(84.7 \pm 2.6 \mathrm{mg}$ as against $110.9 \pm 4.9 \mathrm{mg})$ might also be accounted for by the influence of the estrogen.

These experiments appear to indicate that, as one of the factors involved in the failure of deciduomal response to uterine trauma in immature rats primed with large doses of PMS and HCG, marked drop of the uterine sensitivity in the animals cannot be overlooked.

Summary. Immature rats primed with 40 I.U. PMS and 20 I.U. HCG were ovariectomized and given daily injections of progesterone and estradiol in an optimal dose combination. Uteri of the rats were incapable of forming deciduomata in response to traumatization given during the injection period. Since the priming with PMS and HCG given after ovariectomy did not affect the development of deciduomata under similar experimental conditions, it seems evident that the suppressive effects of the PMS-HCG priming on the uterus were exerted through the ovaries. If doses of PMS and HCG were reduced to 5 and 2 I.U., respectively, formation of deciduomata in response to uterine traumatization under the influence of progesterone plus estradiol was no longer interfered with.

Acknowledgment. The writer is grateful to Dr. S. Kawashima and Mr. T. Mori for their valuable help.

\section{References}

Armstrong, D. T., and R. O. Greep: Endocrinology, 76, 246 (1965).

Guillet, G. C., and E. G. Rennels: Texas Rep. Biol. Med., 22, 78 (1964).

Takewaki, K.: Annot. Zool. Japon., 42, 126 (1969).

Yochim, J. M., and V. J. De Feo: Endocrinology, 71, 134 (1962). 